INFLAMMATION AND INFLAMMATORY BOWEL DISEASE

\title{
Mucin gene expression in the ileoanal reservoir is altered and may be relevant to the risk of inflammation and dysplasia
}

\author{
P A Sylvester, M Walsh, N Myerscough, B F Warren, A P Corfield, M G Thomas, \\ P Durdey
}

Gut 2002;51:386-391

See end of article for authors' affiliations

Correspondence to: Mr P A Sylvester, Coloproctology Unit (Level 4), Bristol Royal Infirmary, Bristol BS2 8HW, UK sylvesterpa@hotmail.com

Accepted for publication 18 December 2001

\begin{abstract}
Background: Adaptive colonic phenotypic change of the ileal mucosa is a feature of the ileoanal reservoir (IAR) with time, as described by mucin glycoprotein and histological analysis. Mucin gene expression is altered in colorectal neoplasia and inflammatory bowel disease but little is known of its expression in the IAR.

Aims: To examine the changes in mucin gene expression contributing to mucosal protection of the IAR against a background of known changes occurring in inflammatory disease and colorectal neoplasia. Patients: Paraffin embedded specimens from 29 "W" and 11 "J" ileoanal reservoirs were studied. Colonic and ileal control tissue was obtained from normal resection margins.

Methods: Mucin mRNA was detected by in situ hybridisation using [ $\left.{ }^{35} \mathrm{~S}\right] \mathrm{dATP}$ labelled oligonucleotide probes. Mucin core protein was detected by immunohistochemistry.

Results: There was no change in mRNA expression of MUC1-4 in the IAR compared with ileal controls but there was a decrease in the protein product of $M U C 1$ and MUC3. No mRNA transcripts of MUC5AC, 5B, or 6 were detected but protein product of MUC5AC and MUC6 was detected. Both cases of MUC6 positivity and 1/5 cases of MUC5AC positivity were confined to the ulcer associated cell lineage. No dysplasia was detected.

Conclusions: There is a change in the pattern of the membrane associated mucins MUC1 and MUC3, part of which is in keeping with changes described in colorectal neoplasia. A small number of cases demonstrated mucin gene changes (MUC5AC) which are seen in early neoplasia and this may provide a valuable monitor for such changes in IAR surveillance.
\end{abstract}

$\mathrm{R}$ estorative proctocolectomy is now regarded as a standard surgical procedure for patients who require proctocolectomy for ulcerative colitis (UC) and familial adenomatous polyposis (FAP). ${ }^{1}$ Adaptive colonic phenotypic change of the ileal mucosa is a feature of the pelvic ileoanal reservoir (IAR). Much of the evidence for phenotypic change has been provided by a change in morphology of the pouch mucosa from a villous small bowel type to a flatter colonic type ${ }^{23}$ and from an associated decrease in pouch mucosal permeability and increase in barrier function. ${ }^{4}$ These changes may also be monitored by studying the pattern of expression of mucins, which form an integral part of the supramucosal defensive barrier in the gastrointestinal tract. ${ }^{5}$ Immunohistochemical and biochemical studies of these glycoproteins in the IAR have shown a change from the sialylated, poorly sulphated, and O-acetylated, small bowel mucin to a more sulphated ${ }^{236}$ and O-acetylated ${ }^{37}$ pattern characteristic of the large bowel mucosa as the phenotype changes. This modification towards a colonic phenotype occurs within the first 9-12 months after IAR construction ${ }^{8}$ but studies of older pouches indicate a predominantly ileal phenotype.'

The risk of neoplasia with increased age of IARs remains a concern although there is little clear evidence that this risk is significant. Two long term studies of morphological changes in the $\mathrm{IAR}^{1011}$ suggest that two groups can be identified. One group shows constant severe acute and chronic inflammation $^{10}$ and the second in which there is constant atrophy with permanent subtotal or total villous atrophy. ${ }^{11}$ Low grade dysplasia has been reported in three patients from two smaller studies ${ }^{12}{ }^{13}$ but there have been no reports of cancer developing within such an area of dysplasia. However, there have been reports of adenocarcinoma within the IAR of patients with $\mathrm{FAP}^{14}$ and arising from the ileoanal anastomosis. ${ }^{16}$ The risk of carcinoma in the IAR of patients with UC is low and only three cases have been described, all of which are most likely attributable to retained diseased rectal mucosa. ${ }^{17-19}$ It is likely that the small columnar cuff $^{20}{ }^{21}$ just above the anal transition zone may be the area most at risk of dysplasia and inflammation. ${ }^{22}$

Mucin changes have been described in association with colorectal neoplasia that involve both mucin gene expression and mucin glycosylation. ${ }^{523}$ IARs in situ for up to five years show no evidence of neoplastic change when analysed for mucin glycosylation and sulphation pattern ${ }^{24}$ but mucin gene expression has not been investigated. Mucin gene expression in colorectal neoplasia includes the de novo switch on of the gastric types MUC5AC and MUC6 against a background of colonic types (MUC2, MUC3, and MUC4), detected at the mRNA $^{25}{ }^{26}$ and peptide levels. ${ }^{26}{ }^{27}$ Increased anti-variable number tandem repeat (VNTR) antibody reactivity to apomucin has also been detected for MUC2 $2^{26}$ and may be related to elevated levels of premature apomucin ${ }^{26}$ or abnormal processing.

The aim of this study was to evaluate changes in mucins contributing to mucosal protection of long term pouches and in particular the risk of neoplasia. Expression of mucin genes was examined against the background of known changes

Abbreviations: IAR, ileoanal reservoir; UC, ulcerative colitis; UACL, ulcer associated cell lineage; FAP, familial adenomatous polyposis; VNTR, variable number tandem repeat; PBS, phosphate buffered saline. 
Table 1 Mucin gene expression in normal human mucosae using an analogue score of 0-4

\begin{tabular}{|c|c|c|c|c|c|c|c|c|c|}
\hline & \multicolumn{9}{|c|}{ Mucin gene } \\
\hline & MUC 1 & MUC 2 & MUC 3 & MUC 4 & MUC 5B & MUC 5AC & MUC 6 & MUC 7 & TRK \\
\hline \multicolumn{10}{|l|}{ Tissue } \\
\hline Colon & 1 & 4 & 1 & 4 & 1 & 0 & 0 & 0 & 0 \\
\hline lleum & 1 & 4 & 0 & 3 & 0 & 0 & 0 & 0 & 0 \\
\hline Jejunum & ND & 4 & 1 & 1 & 2 & 0 & 2 & 0 & 0 \\
\hline Gastric & 2 & 2 & 2 & 0.5 & 0 & 2 & 3 & 0 & 0 \\
\hline Salivary gland & 0 & 0 & 0 & 0 & 3 & ND & 0 & 4 & 0 \\
\hline Bronchus & 1 & 3 & 0 & 2 & 4 & 0 & 0 & 0 & 0 \\
\hline
\end{tabular}

occurring in inflammatory bowel disease and colorectal neoplasia.

\section{PATIENTS AND METHODS}

Twenty nine "W" and 11 "J" reservoirs were studied, with a median (range) age of $8(5-10)$ and $3(1-7)$ years, respectively. Only one patient had a " $\mathrm{J}$ " reservoir constructed for FAP and there were no cases of acute pouchitis. Patients, who were all undergoing yearly surveillance, were endoscoped using a flexible sigmoidoscope. A single random biopsy was taken from the posterior wall of the body of the reservoirs, $10 \mathrm{~cm}$ from the anal verge. Biopsies were immediately preserved in $10 \%$ formal saline and embedded in agar gel within 24 hours. Normal colonic controls were obtained from biopsies taken at negative flexible sigmoidoscopy and from resection margins for chronic constipation. Normal ileal controls were obtained from the resection margin of right hemicolectomy specimens and from the margins at the closure of defunctioning ileostomies.

All tissues were treated in a strictly RNase free manner and $4 \mu \mathrm{m}$ sections of the specimens were cut onto gelatin coated slides for in situ hybridisation or on to Histogrip coated slides for immunohistochemistry. ${ }^{29} 30$

\section{Ethics approval}

Ethics approval for all of the work undertaken was obtained from the United Bristol Hospital Trust Ethics Committee.

\section{In situ hybridisation}

Complementary 48mer oligonucleotide probes were chosen specifically for the tandem repeat sequences of MUC1, 2, 3, 4, 5AC, 5B, 6, TRK, and $\beta$-actin as described previously. ${ }^{29}{ }^{30}$ The oligonucleotides were $3^{\prime}$ end labelled using a terminal deoxynucleotidyl transferase kit (Boehringer Mannheim, Lewes, East Sussex, UK) with ${ }^{35} \mathrm{~S}$-deoxy-adenosine triphosphate (Amersham Life Science, Amersham, Bucks, UK) and were purified with a QIAquick nucleotide removal kit (Qiagen Ltd, Crawley, West Sussex, UK).

In situ hybridisation and signal detection were performed essentially as previously described. ${ }^{29}{ }^{30}$ Autoradiographic detection of the hybridisations was carried out by dipping in $\mathrm{K} 5$ emulsion (Kodak, Ilford, UK) followed by air drying for one hour. Exposure was for 2-3 weeks in a desiccation chamber before development. Sections were counterstained with methyl green pyronin and mounted. Localisation of mucin mRNA was performed from the counterstained slides under light and dark field microscopy. The response of the autoradiographic film was calibrated using ${ }^{14} \mathrm{C}$ radioactive microscale standards (Tocris Cookson, Langford, UK). Semiquantitative assessment of mucin gene expression was made visually from the autoradiographs in relation to the ${ }^{14} \mathrm{C}$ microscale standards as follows: +++ , strong $(1.74-3.0 \mathrm{nCi} / \mathrm{mg})$; ++ , moderate $(0.83-1.6 \mathrm{nCi} / \mathrm{mg})$; + , weak $(0.19-0.7 \mathrm{nCi} / \mathrm{mg})$; and - , negative $(<0.19 \mathrm{nCi} / \mathrm{mg})$. In addition, autoradiographic images of probe bound to mucin messenger RNA, together with ${ }^{14} \mathrm{C}$ labelled standards, were measured using a computer assisted image analysis system (image 1.22 developed by $\mathrm{W}$ Rasband, NIH, Bethesda, Maryland, USA).

\section{In situ hybridisation controls}

The specificity of the oligonucleotide probes was verified and supported by the exclusively epithelial disposition of mucin hybridisation and the absence of expression in the colorectum of TRK (a neurotrophin receptor probe not expressed outside the CNS). The tissue specificity of the probes used in this study is illustrated in table 1 . Competitive studies were performed using either 50 times excess of the same unlabelled probe or an irrelevant probe; in situ hybridisation was negative in normal rectal mucosa and adenomatous tissue with MUC7 acting as an internal negative. To ensure "low background", in situ hybridisation was performed at an optimised temperature and with stringent hybridisation washing at a high temperature close to the calculated probe melting temperature. Mucin gene expression was largely consistent across the replicates and suggests variation in tissue fixation, duration of storage, and prehybridisation processing of paraffin embedded archival tissue did not significantly alter the stability of mucin mRNA and their detection by in situ hybridisation. Individual specimens however were observed with high or low expression.

\section{Immunohistochemistry}

Antibodies to mucin gene peptide sequences were used as described previously. ${ }^{29}{ }^{30}$ The polyclonal antibodies LUM2-3 (MUC2, non-VNTR), ${ }^{31}$ LUM5-1 (MUC5AC, non-VNTR), ${ }^{31}$ and M5B (MUC5B, non-VNTR), ${ }^{32}$ kindly donated by Dr D Thornton and Dr J Sheehan, University of Manchester, UK, and GPEP24 (MUC6, VNTR, kindly donated by Professor I Carlstedt, University of Lund, Sweden) were used at dilutions

Table 2 Autoradiographic scores for in situ hybridisation of mucin (MUC) genes in the ileoanal reservoir (IAR)

\begin{tabular}{|c|c|c|c|c|c|c|c|c|c|c|c|c|}
\hline & \multicolumn{3}{|c|}{$\mathrm{MUCl}$} & \multicolumn{3}{|c|}{ MUC2 } & \multicolumn{3}{|l|}{ MUC3 } & \multicolumn{3}{|l|}{ MUC4 } \\
\hline & C & G & GL & C & G & GL & C & G & GL & C & G & GL \\
\hline Ileum & - & - & $+(4 / 5)$ & - & $+(4 / 5)$ & - & $+(3 / 5)$ & - & - & $+(2 / 5)$ & - & - \\
\hline Colon & - & - & $+(5 / 5)$ & - & $++(5 / 5)$ & - & $+-(2 / 5)$ & - & - & $++(5 / 5)$ & - & - \\
\hline IAR & - & - & $+(33 / 40)$ & - & $+(28 / 40)$ & - & $+(26 / 40)$ & - & - & $+-(12 / 40)$ & - & - \\
\hline
\end{tabular}

C, cytoplasm; G, Goblet cell; GL, glycocalyx. 
A
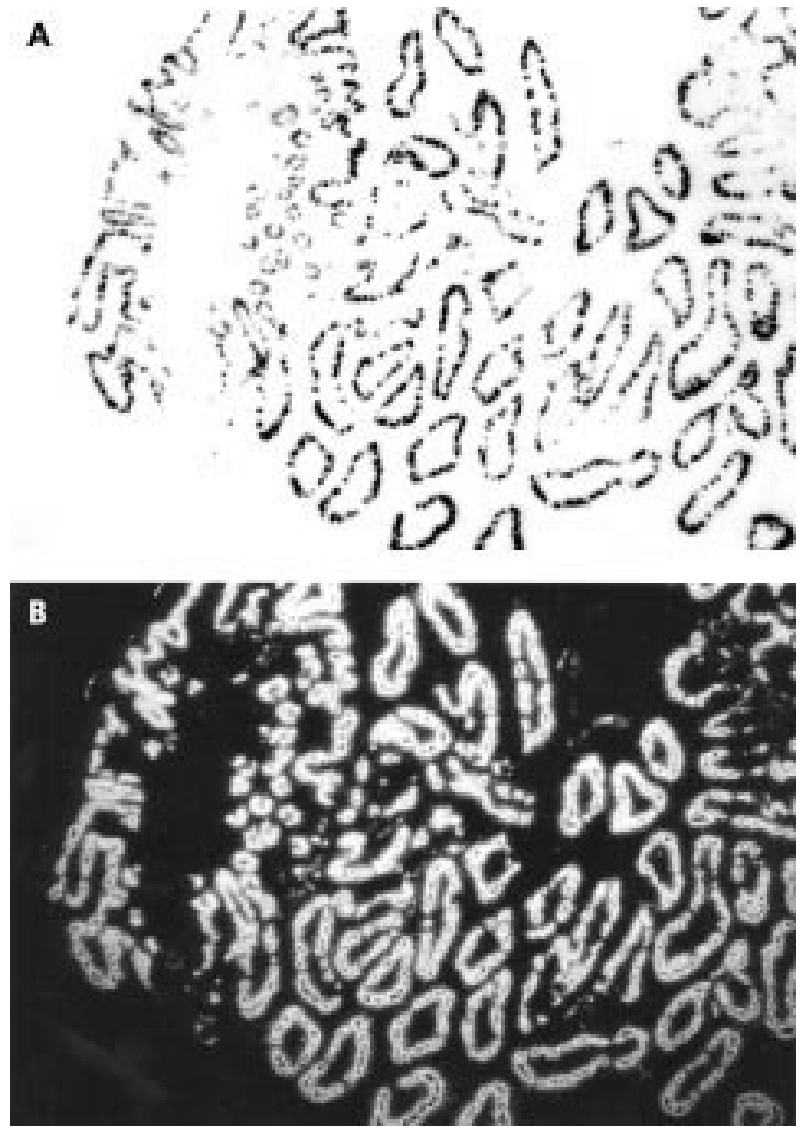

Figure 1 Detection of MUC2 mRNA in the ileoanal reservoir by (A) light phase and (B) dark phase photography after emulsion development of the hybridised specimens.

of 1 in 3000, 1 in 800, 1 in 2500, and 1 in 1000, respectively. Monclonal antibodies BC2 (MUC1, VNTR), ${ }^{33}$ M4.275 (MUC4, VNTR), ${ }^{34}$ and M3.3 (MUC3, VNTR) ${ }^{35}$ were initially diluted in phosphate buffered saline (PBS) containing 10\% non-immune goat serum: 1:2000 for BC2, 1:1000 for M4.275, and 1:100 for M3.3.

Sections were processed as described previously. ${ }^{29}{ }^{30}$ Endogenous peroxidase activity was blocked in 3\% ( $/ \mathrm{v})$ hydrogen peroxide (MUC2, $5 \mathrm{AC}, 5 \mathrm{~B}$, and 6 ) or $1.0 \% \mathrm{H}_{2} \mathrm{O}_{2} / 0.1 \%$ sodium azide (MUC1, 3, and 4). Antigen retrieval was performed by pressure cooking at $121^{\circ} \mathrm{C}$ for 85 seconds in $10 \mathrm{mM}$ citrate buffer, $\mathrm{pH}$ 6.0, and tissue sections left to cool at room temperature for 20 minutes (MUC2, 5AC, 5B, and 6) or in citric acid buffer ( $\mathrm{pH} 6)$ using a microwave set to high for eight minutes and repeated (MUC1, 3, and 4). MUC2 antisera also required reduction in $10 \mathrm{mM}$ dithiothreitol in $10 \mathrm{mM}$ Tris/ $\mathrm{HCl}$, $\mathrm{pH} 8.0$, at $37^{\circ} \mathrm{C}$ for 30 minutes.

Polyclonals to MUC2, MUC5AC, MUC5B, and MUC6 were incubated for one hour at room temperature. ${ }^{30}$ After washing in PBS they were incubated with secondary reagent, 1 in 100 goat antirabbit horseradish peroxidase conjugate in PBS for 25 minutes at room temperature before visualisation with 3-3' diaminobenzidine.

Mouse monoclonal antibodies were incubated at room temperature for 45 minutes (BC2) and overnight (M3.3 and M4.275). Following incubation, sections were washed thoroughly in three changes of PBS for five minutes each, the first wash containing $1 \% \mathrm{v} / \mathrm{v}$ Triton X-100. Sections were incubated with biotinylated goat antimouse immunoglobulins for 15 minutes (BC2) and 30 minutes (M3.3 and 4.275) and then with streptavidin-biotin-horseradish peroxidase conjugate for 15 minutes.

Visualisation of polyclonal and monclonal antibodies was by development in $0.6 \mathrm{mg} / \mathrm{ml} \mathrm{3-3} \mathrm{diaminobenzidine/0.03 \%}$ $(\mathrm{v} / \mathrm{v})$ hydrogen peroxide in PBS, water washing, counterstaining with haematoxylin, dehydration, clearing, and mounting as previously described. ${ }^{29} 30$

\section{Positive and negative controls}

Staining of the control tissues named above confirmed the expected pattern of positivity for the antisera tested (table 1). As a further control, competition studies using purified human colonic and respiratory mucins were performed. Mucins were purified from resected colorectal mucosa or human respiratory tract lavage samples using triple density gradient centrifugation in $\mathrm{CsCl}^{36}$ These showed the ability to abolish the LUM2-3 (MUC2) colonic epithelial staining with $10 \%$ purified colonic mucin (that is, MUC2) but not with purified $10 \%$ respiratory mucin (MUC5AC and MUC5B). Moreover, attenuation of MUC2 and MUC5AC staining was in a dose dependent manner. Specific reactivity of LUM5-1 in bronchial epithelial tissue was abolished with $10 \%$ respiratory mucin (that is, MUC5AC and MUC5B) but not with purified colonic mucin. The use of $10 \%$ bovine serum albumin did not abolish LUM2-3 or LUM5-1 staining. Positive controls for BC2, M3.3, and M4.275 were normal colon; negative controls were stained as above but with PBS alone substituted for the primary antibody.

All sections were viewed by PAS/MDW (MUC1, 3, and 4) and PAS/BFW (MUC2, 5AC, 5B, and 6) using a conference microscope and a note made of the proportion of positive cells and cellular localisation. The proportion of cells staining was estimated in quartile groupings: $1(0-25 \%) ; 2(25-50 \%) ; 3$ $(50-75 \%)$; and $4(75-100 \%)$.

\section{Statistical analysis}

Analysis was performed with the Unistat Software using the Mann-Whitney U test for non-parametric data.

\section{RESULTS}

\section{In situ hybridisation}

Autoradiographic scores (0-4) for biopsies of the IAR are shown in table 2. The level of MUC2 and MUC4 mRNA was higher in colorectal controls when directly compared with ileal controls $(p<0.03)$; there was no difference in levels of MUCl and MUC3 (table 2). There was no change in the level of mRNA transcripts detected for MUCl-4 in the IAR compared with ileal controls (fig 1). No MUC5AC, 5B, or 6 transcripts were detected in either the test or control tissue.

Table 3 Scores for immunohistochemical staining of mucin (MUC) gene product in the ileoanal reservoir (IAR)

\begin{tabular}{|c|c|c|c|c|c|c|c|c|c|c|c|c|c|}
\hline & \multicolumn{3}{|c|}{$\mathrm{MUCl}$} & \multicolumn{3}{|c|}{ MUC2 } & \multicolumn{4}{|c|}{ MUC3 } & \multicolumn{3}{|l|}{ MUC4 } \\
\hline & $\mathrm{C}$ & G & $\mathrm{GL}$ & C & G & & $\mathrm{GL}$ & $\mathrm{C}$ & G & GL & C & G & GL \\
\hline Ileum & - & - & $+(8 / 9)$ & - & $++(7 / 7)$ & - & $++(7 / 7)$ & & - & - & $+(6 / 8)$ & - & - \\
\hline Colon & - & - & $+++(7 / 7)$ & - & $+++(6 / 6)$ & - & $+++(7 / 7)$ & & - & - & $++++(7 / 7)$ & - & - \\
\hline IAR & - & - & $+-(12 / 40)$ & - & $+++(40 / 40)$ & - & $+(32 / 40)$ & - & & - & $+(28 / 40)$ & - & - \\
\hline
\end{tabular}

C, cytoplasm; G, Goblet cell; GL, glycocalyx. 

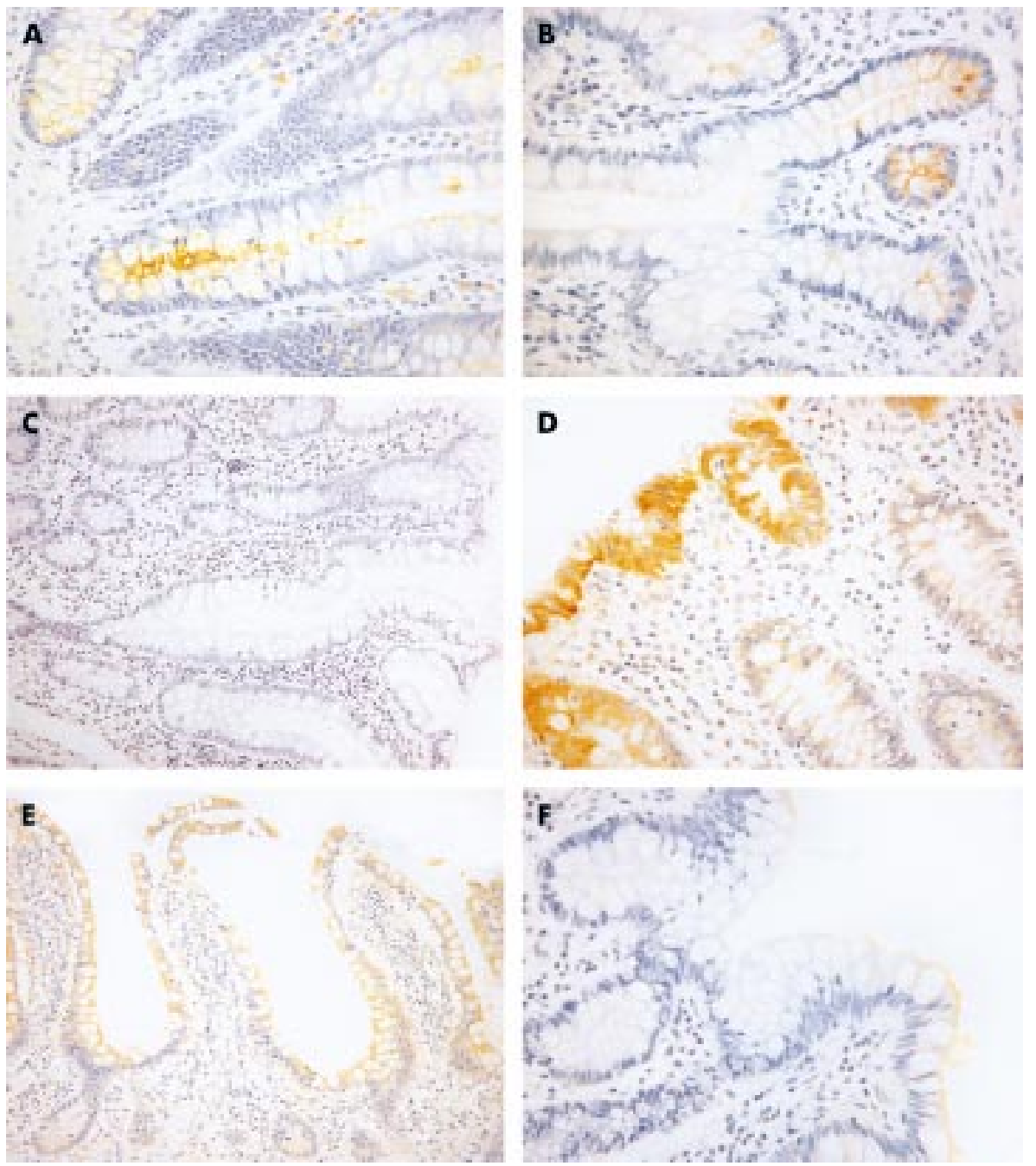

Figure 2 Detection of $M U C 1$ and $M U C 3$ protein product $(\times 40)$ by immunohistochemical staining with $B C 2(M U C 1)$ and $M 3.3(M U C 3)$. (A) Normal colon (MUC1); (B) normal ileum (MUC1); (C) ileoanal reservoir (MUC1); (D) normal colon (MUC3); (E) normal ileum (MUC3); and (F) ileoanal reservoir (MUC3).

\section{Immunohistochemistry}

Immunohistochemical scores for mucin detection in the IAR are shown in table 3. Detection of MUC1 protein product was greatest in the deep glands, with predominantly apical staining of epithelial cells. MUC3 and MUC4 were largely detected in cytoplasm, with MUC3 being detected mainly at the top of the crypt. MUC4 staining was strongest in the deep glands. The protein product of MUC2 was predominantly detected in the goblet cell, with staining most marked in goblet cell vesicles. MUC5AC was not detected in large or small bowel control tissues.

There was a smaller percentage of cells that stained for MUC1, 3, and 4 protein product in ileal controls compared with colorectal controls $(\mathrm{p}<0.003)$ (table 3$)$. There was no difference for MUC2 and there was no positivity in control tissues for MUC5AC, 5B, or 6 . There was a decrease in the level of MUCl $(\mathrm{p}<0.004)$ and MUC3 $(\mathrm{p}<0.001)$ protein product in the IAR compared with ileal controls (fig 2 ). There was no correlation between inflammatory score and detection of the protein products of MUCl-4. There was no association between the degree of morphological change (villous, partial villous, and flat) and level of expression of MUC1, 2, and 4. Level of expression of MUC3 was less in those biopsies which retained their villous morphology $(n=25)$ compared with those which had undergone partial villous atrophy $(n=12): 0.72(0.09)$ versus $1.00(0)(p<0.05)$. Only three

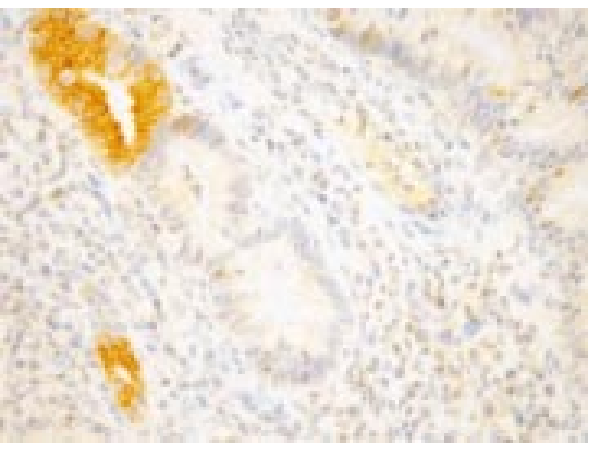

Figure 3 Detection of MUC6 protein product in ulcer associated cell lineage present in ileoanal reservoir mucosa $(\times 40)$.

biopsies had flat mucosa such that statistical comparison was not possible. There was sporadic MUC5AC and MUC6 protein product detected in five and two reservoirs, respectively. Positivity for MUC6 was present in ulcer associated cell lineage (UACL) in both cases (fig 3) whereas only one of the MUC5AC positive pouch biopsies was present in UACL. Two of the five biopsies positive for MUC5AC and one of two positive for MUC6 had flat mucosa. No dysplasia was found in any of the 40 reservoirs studied. 


\section{DISCUSSION}

Changes in the morphology ${ }^{3}$ and mucin biology ${ }^{9}$ of the IAR mucosa with time after construction have been identified. In addition, there are indications that dysplasia may arise in a few case $^{11}$ and development of neoplasia with increasing IAR age remains a concern. A number of studies have demonstrated that analysis of the epithelial mucins at the histochemical, biochemical, and genetic levels have the potential to predict and monitor the progression of gastrointestinal disease $^{5}$ and this is also reflected in previous work on the IAR.

Expression of mucin genes and their mature products is known to be altered in colorectal neoplasia. ${ }^{23} 37$ In UC, no change in MUC2 mRNA levels could be found ${ }^{38-40}$ and no association with MUC2 allele length was apparent. ${ }^{41}$ However, differences in immunoreactive MUC2 have been reported in active disease. ${ }^{38}{ }^{40}$ No study has been carried out in the IAR to assess the MUC gene pattern with respect to pouch adaptation or development of dysplasia.

The findings presented here for IAR mucosa showed decreases in immunodetectable MUCl and MUC3 levels while mRNA expression for these genes remained constant (tables 2,3 ). This pattern is reminiscent of studies in UC where MUC2 mRNA levels were unchanged but immunoreactive MUC2 showed a significant increase ${ }^{38}$ or decrease $e^{40}$ depending on the antibody used. This has been explained in terms of changes in post translational modifications. A similar interpretation can be made for results obtained here with MUC1 and MUC3. Our findings imply that no alteration in mRNA levels are seen and that antibody analysis detects events that occur to the peptide through proteolytic cleavage, glycosylation, or subcellular targeting, which would be reflected in modified binding of the products with antimucin antibodies. Evidence for this type of behaviour using different anti-MUC2 antibodies to VNTR and non-VNTR peptide domains has been reported. ${ }^{42}$

The anti-MUCl and anti-MUC3 antibodies used in this study are directed against the VNTR peptide sequences of these genes and it is possible that glycosylation may affect the binding properties of antibodies. Glycosylation changes have been detected in IAR related to adaptation ${ }^{43}$ and which occur without significant visible morphological modification. In UC, such differences in glycosylation are also apparent between groups of patients with similar and typical inflammatory bowel disease related morphology. ${ }^{44}$ At present, no anti-MUCl or anti-MUC3 antibodies are available that allow discrimination between glycosylation patterns in these membrane associated mucins.

Detection of differences in gene expression in MUC 1 and MUC3 as adaptation occurred showed levels that were lower in biopsies with no or minimal change to the villous architecture. Retention of the ileal phenotype argues against any changes in MUCl and MUC3, reflecting a colonic phenotype, although initial steps in this adaptation may involve alteration of glycocalyx targeted mucins.

This study provides no support for the appearance of dysplasia or neoplastic change within the period of the pouches studied. In this respect, sporadic expression of MUC5AC and MUC6 may be relevant as both have been shown to be aberrantly expressed in colorectal neoplasia. ${ }^{25} 26$ The number of cases concerned was small but the three biopsies which showed significant colonic phenotypic change to a flat mucosa also expressed either MUC5AC or MUC6 protein products but not both. In one of these cases staining was confined to an area of UACL.

It is essential to consider that the biopsies studied were random and single but taken from the posterior body of the IAR, the region most at risk of adaptive change. ${ }^{3}$ Ideally, several biopsies should be studied to decrease the likelihood of missing an area of dysplasia, although within the bounds of reality this in itself would not be an absolute guarantee. This study does however give an indication of gene expression dur- ing the adaptive process. It should be borne in mind that the controls were from separate individuals not suffering from UC. The colorectum of UC patients would be diseased and hence not useful whereas ileal controls would be available but should be similar to those from patients without UC.

Thus in conclusion, this study demonstrates a changed pattern of the membrane associated mucins MUCl and MUC3, possibly at a post translational level, in the IAR, part of which is in keeping with changes described in colorectal neoplasia. No evidence of significant dysplasia was observed in this study although a small number of cases showed mucin gene changes which are seen in neoplasia and may provide a valuable monitor for such changes in routine IAR surveillance.

\section{Authors' affiliations}

P A Sylvester, M G Thomas, P Durdey, Department of Surgery, Bristol Royal Infirmary, Bristol, UK

M Walsh, Department of Pathology, University of Queensland,

Queensland, Australia

N Myerscough, A P Corfield, Department of Medicine, Bristol Royal Infirmary, Bristol, UK

B F Warren, Department of Cellular Pathology, John Radcliffe Hospital, Oxford, UK

\section{REFERENCES}

1 Williams NJ. Restorative proctocolectomy is the first choice elective treatment for ulcerative colitis. Br J Surg 1989;76:1 109-10.

2 Shepherd NA, Jass JR, Duval I, et al. Restorative proctocolectomy with ileal reservoir: pathological and histochemical study of mucosal biopsy specimens. J Clin Pathol 1987;40:601-7.

3 Shepherd NA, Healey CJ, Warren BF, et al. Distribution of mucosal pathology and an assessment of colonic phenotypic change in the pelvic ileal reservoir. Gut 1993:34:101-5.

4 Merrett MN, Soper N, Mortensen N, et al. Intestinal permeability in the ileal pouch. Gut 1996;39:226-30.

5 Corfield AP, Longman R, Sylvester PA, et al. Mucins and mucosal protection in the gastrointestinal tract: New prospects for mucins in the pathology of gastrointestinal disease. Gut 2000;47:589-94.

6 de Silva HJ, Millard PR, Kettlewell MGW, et al. Mucosal characteristics of pelvic ileal pouches. Gut 1991;32:61-5

7 Campbell AP, Merrett MN, Kettlewell MGW, et al. Expression of colonic antigens by goblet and columnar epithelial cells in ileal pouch mucosa: Their association with inflammatory change and faecal stasis. $J$ Clin Pathol 1994;47:834-8.

8 Corfield AP, Warren BF, Bartolo DCC, et al. Mucin changes in ileoanal pouches monitored by metabolic labelling and histochemistry. Br J Surg 1992;79:1209-12.

9 Sylvester PA, Wong NACS, Myerscough N, et al. Mucin expression in the ileoanal reservoir reflects incomplete mucosal adaptation. J Pathol 2002; 197:28-36

10 Setti-Carraro P, Talbot IC, Nicholls RJ. Longterm appraisal of the histological appearances of the ileal reservoir mucosa after restorative proctocolectomy for ulcerative colitis. Gut 1994:35:1721-7.

11 Veress B, Reinholt FP, Lindquist K, et al. Long-term histomorphological surveillance of the pelvic ileal pouch: dysplasia develops in a subgroup of patients. Gastroenterology 1995;109:1090-7.

12 Veress B, Reinholt FP, Lindquist K, et al. Different types of mucosal adaptation in the ileal reservoir after proctocolectomy. APMIS 1990;98:786-96

13 Lofberg R, Liljeqvist L, Lindquist K, et al. Dysplasia and DNA aneuploidy in a pelvic pouch. Dis Colon Rectum 1991;34:280-4.

14 Bassuini MMA, Billings PJ. Carcinoma in an ileoanal pouch after restorative proctocolectomy for familial adenomatous polyposis. $\mathrm{Br} J$ Surg 1996;83:506

15 Malassagne M, Penna C, Parc R. Adenomatous polyps in the anal transitional zone after ileal pouch-anal anastomosis for familial adenomatous polyposis: treatment by transanal mucosectomy and ileal pouch advancement. Br J Surg 1995;82:1634

16 Hoehner JC, Amanda MM. Development of invasive adenocarcinoma following colectomy with ileoanal anastomosis for familial polyposis coli. Dis Colon Rectum 1994;37:824-8.

17 Stern H, Walfisch S, Mullen B, et al. Cancer in an ileoanal reservoir: a new late complication? Gut 1990;31:473-5.

18 Puthu D, Rajan N, Rao R, et al. Carcinoma of the rectal pouch following restorative proctocolectomy. Dis Colon Rectum 1992;35:257-60.

19 Ravitch MM. Presidential Address: The reception of new operations. Ann Surg 1984;200:231-46.

20 Thompson-Fawcett MW, Mortensen NJMcC. Anal transition zone and columnar cuff in restorative proctocolectomy. Br J Surg 1996;83: 1047-55.

21 Thompson-Fawcett MW, Warren BF, Mortensen NJ. A new look at the anal transitional zone with reference to restorative proctocolectomy and the columnar cuff. Br J Surg 1998;85:1517-21. 
22 Thompson-Fawcett MW Warren BF, Mortensen NJ. Cuffitis and inflammatory changes in the columnar cuff, anal transitional zone and ileal reservoir after stapled pouch anastomosis. Dis Colon Rectum 1999;42:348-55.

23 Kim YS, Gum J, Brockhausen I. Mucin glycoproteins in neoplasia. Glycoconjugate J 1996;13:693-707.

24 PA Sylvester, J Davies, N Wong, et al. Expression of neoplasia-associated mucin carbohydrates within the ileoanal reservoir (IAR). Int J Colorectal Dis 1999;1(suppl 1):49.

25 Busine M-P, Janin A, Maunoury V, et al. Aberrant expression of a human mucin gene (MUC5AC) in rectosigmoid villous adenomas. Gastroenterology 1996;1 10:84-91.

26 Bartman AE, Sanderson SJ, Ewing SL, et al. Aberrant expression of MUC5AC and MUC6 gastric mucin genes in colorectal polyps. Int $J$ Cancer 1999:80:210-18.

27 Beimer-Huttmann AE, Walsh MD, McGuckin MA, et al. Immunohistochemical staining patterns of MUC1, MUC2, MUC4 and MUC5AC mucins in hyperplastic polyps and traditional adenomas of the colorectum. J Histochem Cytochem 1999;47:1039-48.

28 Blank M, Klussmann E, Kruger-Krasagakes S, et al. Expression of MUC2mucin in colorctal adenomas and carcinomas of different histological types. Int J Cancer 1994;59:301-6.

29 Arul GS, Moorghen M, Myerscough N, et al. Mucin gene expression in Barrett's oesophagus, an in situ hybridisation and immunohistochemical study. Gut 2000;47:753-61.

30 Longman RJ, Douthwaite J, Sylvester PA, et al. Co-ordinated expression of mucin and trefoil peptide genes in the ulcer associated cell lineage and the gastrointestinal mucosa. Gut 2000;47:792-800

31 Hovenberg HW, Davies JR, Herrman A, et al. MUC5AC, but not MUC2, is a prominent mucin in respiratory secretions. Glycoconjugate J 1996; 13:839-47.

32 Thornton DJ, Howard M, Khan N, et al. Identification of two glycoforms of the MUC5B mucin in human respiratory mucus - Evidence for a cysteine-rich sequence repeated within the molecule. J Biol Chem 1997; 272:9561-6.
33 Xing PX, Prenzoska J, Quelch K, et al. Second generation anti-MUC 1 peptide monoclonal antibodies. Cancer Res 1992;52:2310-17.

34 Xing PX, Prenzoska J, Apostolopoulos V, et al. Monoclonal antibodies to a MUC4 peptide react with lung cancer. Int J Oncol 1997;1 1:289-95.

35 Apostolopoulos V, Xing PX, McKenzie IF. Anti-peptide monoclonal antibodies to intestinal mucin3. Gastroenterol Hepatol 1995; 10:555-61.

36 Davies JR, Carlstedt I. Isolation of large gel forming mucins. In: Corfield AP, ed. Glycoprotein methods and protocols. The mucins. 125. Totowa, USA: Humana Press, 2000:3-13.

37 Lesuffleur T, Zweibaum A, Real FX. Mucins in normal and neoplastic human gastrointestinal tissues. Crit Rev Oncol Haematol 1994; 17:153-80.

38 Hanski C, Born M, Foss D, et al. Defective post-transcriptional processing of MUC2 mucin in ulcerative colitis and in Crohn's disease increases detectability of the MUC2 protein core. J Pathol 1999:188:304-11.

39 Myerscough N, Warren BF, Gough M, et al. Expression of mucin genes in ulcerative colitis. Biochem Soc Trans 1995;23:536S

40 Tytgat KMA, Van der Wal T-W, Einerhand AWC, et al. Quantitative analysis of MUC2 synthesis in ulcerative colitis. Biochem Biophys Res Commun 1996;224:397-405.

41 Swallow DM, Vinall LE, Gum JR, et al. Ulcerative colitis is not associated with differences in MUC2 mucin allele length. J Med Genet 1999;36:859-60

42 Askoy N, Thornton DJ, Corfield A, et al. A study of the intracellular and secreted forms of the MUC2 mucin from the PC/AA intestinal cell line. Glycobiology 1999;9:739-46.

43 Bahia SS, McMahon RTF, Hobbiss J, et al. Pelvic ileoanal reservoirs: a lectin histochemical study. Histochem J 1993;25:392-400.

44 McMahon RF, Warren BF, Jones CJ, et al. South Asians with ulcerative colitis exhibit altered lectin binding compared with matched European cases. Histochem J 1997;29:469-77.

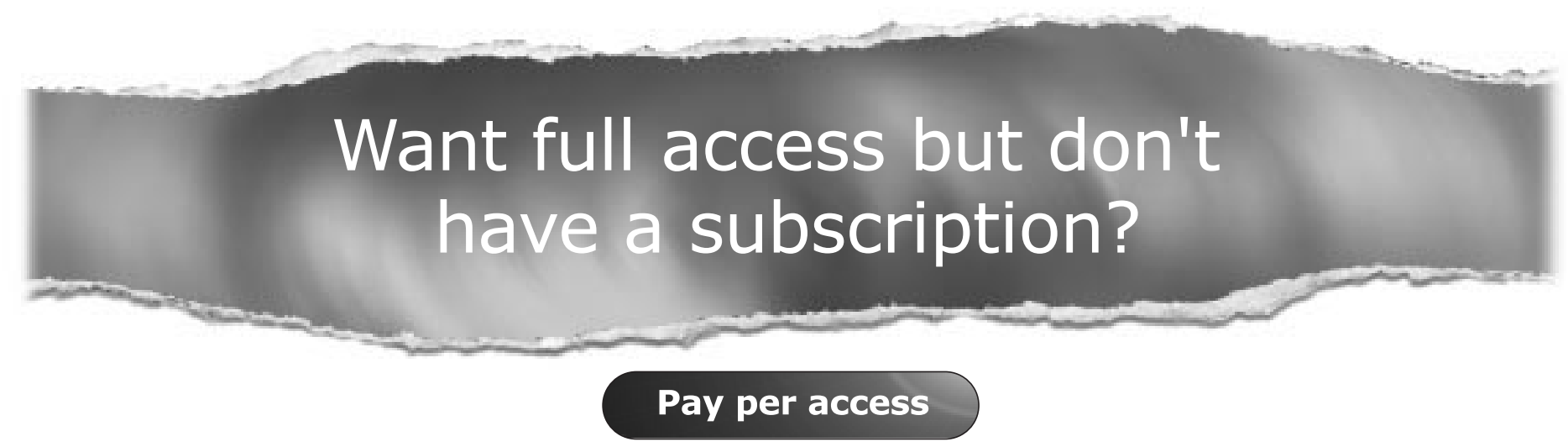

For just US $\$ 25$ you can have instant access to the whole website for 30 days. During this time you will be able to access the full text for all issues (including supplements) available. You will also be able to download and print any relevant pdf files for personal use, and take advantage of all the special features Gut online has to offer.

\section{www.gutjnl.com}

